\title{
Preaching between affirmation and anticipation: contours of a paradoxical homiletic ${ }^{1}$
}

\author{
Cilliers, Johan \\ Stellenbosch University ${ }^{2}$ \\ jcilliers@sun.ac.za
}

\begin{abstract}
Taking the many paradoxes that the South African society is currently facing as point of departure, this article sets out by defining the notion of paradox, followed by the drawing of a few contours of a homiletic that endeavours to preach the promises of God within, and against, these paradoxes. Four movements are identified in this process, namely preaching as affirmation, provocation, migration, and anticipation. The article ends with a reflection on a well-known artwork by former South African president, Nelson Mandela.
\end{abstract}

\section{Keywords}

Paradox, Promise, Affirmation, Provocation, Migration, Anticipation

\section{Paradox?}

"A nation of paradoxes." That is how Mary Robinson, the United Nations Human Rights Commissioner and former president of Ireland, described South Africa when she delivered the tenth Nelson Mandela Annual Lecture in Cape Town in August of 2012. ${ }^{3}$ In a moving speech, speaking as "an outsider, but a genuine friend" she listed a number of reasons why this country could indeed be called a place of paradoxes. She mentioned,

1 Edited version of presidential address delivered at the twelfth biannual conference of the Societas Homiletica, held in Stellenbosch, South Africa, 11-16 March 2016 on the theme: Preaching Promise within the Paradoxes of Life.

2 Professor in Homiletics and Liturgy at the Faculty of Theology, University of Stellenbosch, South Africa.

3 Freedom, truth, democracy: citizenship and common purpose. https://www. nelsonmandela.org/.../transcript-of-mary-robinsons-nelson 
amongst other things, the grinding poverty and hopelessness of the population in the Eastern Cape, in contrast to her experiences in a so-called rich enclave in the town Paarl in the Western Cape - and she could not believe that the two realities existed in the same country. She praised the remarkable progress being made in female representation in the political arena, noting that 41percent of cabinet positions were at that stage held by women; that five of the nine provincial premiers were women and that 42 percent of the seats in parliament were occupied by women. But she added: "There is a darker side", describing the rape and murder statistics and the still-prevalent and increasing abuse of women. She was amazed at the apparent thriving of civil society in South Africa, but lamented the fact that this same society, inclusive of the religious leaders, often, and paradoxically, seems disengaged. She stated, and I quote:

Are they doing enough? Are they truly working to hold government to account for the inequities, the imbalances, the injustices they witness close to home? Or are they more concerned with their own survival, their own advancement, to the detriment of that wider common purpose of achieving a constitutional democracy: that vision of a united, non-racist, non-sexist, democratic and prosperous South Africa? ${ }^{4}$

A nation of paradoxes, indeed - and the list substantiating this claim could be lengthened; apparently ad infinitum. This is however, nothing new. After an American journalist, Allen Drury, visited South Africa in the late 1960's, he felt the need to write a book entitled: A Very Strange Society. ${ }^{5}$ That we are, indeed. Our own beloved Archbishop Desmond Tutu called us the "Rainbow Nation", but, at the same time, he wondered: "Who in their right mind could have believed South Africa could be an example of anything but the most awful ghastliness? We are such an unlikely lot."

But, who knows, perhaps it is exactly because we are such an unlikely lot, that the unexpected, dare I say the unexpected touch of grace, might be felt in this paradoxical place. One of our other "prophets" from the

\footnotetext{
4 Freedom, 5.
}

5 Allen Drury, A Very Strange Society. A journey to the Heart of South Africa (New York: Trident Press, 1967).

6 BBC News, January 2000. 
apartheid era, Dr Beyers Naudé, was of the opinion that South Africa is a microcosm of the contemporary world, where "white and black, East and West, rich developed First World and poor developing Third World meet as in no other country in the world", and he added: "...this sets a tremendous challenge, but it is also a unique privilege. In the meltingpot of this meeting Christians who want to live out their faith have an incomparable opportunity to witness to justice, love of neighbour, truth and compassion."7

Paradox. This is also one of the keywords that keep on coming back when one endeavours to define preaching. It is not such an easy concept to describe. The official definition of paradox - or at least one of them differentiates between different levels of meaning, calling it:

"A seemingly absurd or contradictory statement or proposition which when investigated may prove to be well founded or true." But also: "A statement or proposition which, despite sound (or apparently sound) reasoning from acceptable premises, leads to a conclusion that seems logically unacceptable or self-contradictory." And, of course, just to bring it closer to home: "A person or thing that combines contradictory features or qualities in him/her or itself." ${ }^{8}$

We are our biggest paradox. I am. But perhaps paradox is also inevitable, particularly when we try to speak about God, i.e. when we try to preach the promise(s) of God. Obviously, the promise(s) of God can be, and indeed has been, described in many ways. There are many promises of God, as multicoloured as God's grace. ${ }^{9}$ God promises us peace beyond understanding; justice that will roll down like waters, and righteousness like an everflowing stream; care surpassing that of the lilies of the field and the birds of the air, and many, many more. ${ }^{10}$

7 Translated from Pro Veritate, 15 January 1972, pp. 5-7, 20. Quoted from Len Hansen and Robert Vosloo, Oom Bey for the Future: Engaging the Witness of Beyers Naudé (Stellenbosch: Sun press, 2006), 1.

8 Oxford English Dictionary. Editors: William Craigie, James Murray, John Simpson (Oxford: Oxford University Press, 1992), "Paradox".

9 Cf. 1 Peter 4:10: Poikilos, translated as "multifaceted" or "multi-coloured" grace.

10 Cf. Philippians 4:7; Amos 5:24; Matthew 6: 26-28. 
For me, all of these promises of God hinge on the trustworthiness, i.e. the faithfulness of God's continued presence with us. The golden thread running through all of God's promises is God's enduring relationship with us. There is a theological connection, an inherent unity and correlation between God's faithfulness and God's promises, i.e. between teleios (that which God brings to fruition) and promissio (that which God promised to bring to fruition). ${ }^{11}$ The faithful Promise of God creates hope, but this hope "... is not a principle founded by the potentiality inherent in creation or material matter. Hope is a Person, based upon the fulfilled promises of a suffering and living God." 12

So, how do you preach this Person as Promise, and Promise as Person? In their book about the foolishness of preaching, Campbell and Cilliers come, inter alia, to the following conclusion:

Theologians have often tried to interpret these images (of the faithful presence of God; JC) in the language of paradox. God is present in this world, and is revealed sub contrario (in contradictions). Or in the words of Hendrikus Berkhof: "[God] can be present in [God's] world only as a stranger, the suffering servant, the crucified one. The concept of paradox is suitable here: God is present contrary to (para) the appearance (doxa) of the opposite." ${ }^{13}$ However, while "paradox" does capture the tensions inherent in the foolishness of the gospel, it is, as Berkhof suggests, fundamentally a reference to human limitations... we human beings, and especially we preachers, function with human language and concepts. God is transcendent, we might say, not through some majestic grandness, which we can comprehend, but rather through embodied folly. So we resort to paradox, unable to disentangle the seeming contradictions, having to live in the tensive space between them....At the heart of the preacher as fool lies the profound paradox of a God whom we know in contradictions. ${ }^{14}$

11 Daniël Johannes Louw, Wholeness in Hope Care. On Nurturing the Beauty of the Human Soul in Spiritual Healing (Wien: Lit Verlag, 2015), 48.

12 Louw, Wholeness in Hope Care, 320.

13 Hendrikus Berkhof, Christian Faith (Grand Rapids: Eerdmans, 1979), 54.

14 Charles L. Campbell and Johan H. Cilliers, Preaching Fools. The Gospel as a Rhetoric of Folly (Waco, Texas: Baylor University Press, 2012), 54. 
In short: The Promise of God's Person and Presence can only be preached in and through Paradox. Paradox is something situated beside or outside the doxa (popular opinion). Paradox is free of all doxa, but at the same time calls the doxa into question. ${ }^{15}$ It is indeed para-doxa; swimming against the stream of public or popular opinion, and contradicting apparent appearances. And, if I may for a moment use the term doxa as we theologians have come to understand it: paradox runs against the grain of what we often understand to be glorious or even holy. Paradox - the Paradox of the Promise of God's Person and Presence - more often than not contradicts what we tend to praise as worthy. ${ }^{16}$

Paradox, also from a theological viewpoint, is more than a set of complications, whether they are issues or conditions or concepts that we strive to solve or dissolve, and which we find difficult to harmonise. ${ }^{17}$ It is not like a mathematical formula, say $2 \times 2=4$; rather, it represents complifications, i.e. a set of circumstances, or web of notions and ideas that are intertwined in such a manner that it cannot necessarily be solved

15 Jacques Ellul, The Humiliation of the Word, trans. Joyce Main Hanks (Grand Rapids, Michigan: William B. Eerdmans Publishing Co., 1985), 24.

16 According to Martin Luther, the most fundamental paradox of all theology is that of the Deus absconditus-Deus revelatus (204). Cf. Bertold Klappert, Promissio und Bund. Gesetz und Evangelium bei Luther und Barth (Göttingen: Vandenhoeck \& Ruprecht, 1976), 204.

17 I take my cue here from the so-called chaos theory or theory of complexity. Within this paradigm, chaos is not viewed as the negative of order; it is not not-order. The Greeks already understood chaos as the possibility for order, as space and horizon filled with potential (Möglichkeitshorizont). Bianca Theisen, Chaos-Ordnung, Ästhetische Grundbefriffe 1 (Stuttgart, Weimar: J.B. Metzler, 2010), 754. In this sense, beauty (or: wholeness) could be interpreted as the dialectic or paradox, i.e. as the perpetual and reciprocal movement between chaos and order. Disproportion of chaos is not the deformity of proportionate order. Chaos is something in itself - as is order. The link between these two realities could be described as beauty. Beauty exists in the tentative space between proportionate order and disproportionate chaos. The quest for beauty is sparked off by this tension; it is perpetually energised by the movement from disproportion to proportion, i.e. from chaos to order. Understood in this sense, beauty therefore does not exclude the ugly (or: disproportionate), but in fact incorporates it in its quest for (healing of) proportion. The very existence of the tension created by disproportion kindles a faith that is in search of beauty (fides quaerens pulchrum). Cf. Johan Cilliers, Fides Quaerens Pulchrum: Practical Theological Perspectives on the Desire for Beauty. Scriptura: International Journal for Bible, Religion and Theology in Southern Africa 2011; 3 (108): 257-268. Against this background, one could perhaps say that the "paradoxes" to which Mary Robinson referred, should rather be called "contradictions", which should urgently be solved, and in no way be either deified or seen as a harmless state of affairs. 
and dissolved, but the acknowledgement and understanding of these complifications, albeit fragmentarily, sensitises one for the potential for discovery, for the expectation of the strange twists and turns within these paradoxes - in so far as one can expect the unexpected. Paradoxes, seen from this perspective, are or could be problematic, but may also harbour possibilities of new beginnings, of new life, of hope. In this sense paradoxes do swim against the stream of what seems to be evident or is commonly believed, but it also goes further and deeper. The para of paradox does not take the paradox out of life, but in fact returns it - and us - to life, in the hope of kindling new life, of stimulating new understanding, of initiating true behavioural transformation. In this "chaosmos of life", ${ }^{18}$ or "beautiful chaos of being", ${ }^{19}$ paradox is neither deified nor eternalised, nor is the myth of equilibrium and manageable stability accepted. On the contrary, the paradoxes of life are viewed as heuristic and transformative spaces. ${ }^{20}$

May I coin a term, perhaps using the notion of paradox in a paradoxical way? Paradox is "outside" of doxa, in order to transform doxa, and, in doing so, it is also "inside" doxa, or at least it returns to doxa. It is not only paradoxum (the Latin version of paradox), but also intradoxum. ${ }^{21}$ Things that are paradoxical are also, simultaneously, intradoxical, and in this sense, it resonates with, and within, life. The paradox as intradox lies within us, within me. We - you and I - can therefore never speak of paradox in a so-called "objective" manner; on the contrary...

So, let me try and do the intradoxical paradoxical, and articulate a few tensions that, in my opinion, are part and parcel of the challenge of preaching God's Promise within the paradoxes of life - obviously an open-

18 Cf. A. Montuori, Foreword. Edgar Morin's Path of Complexity. In: E. Morin, On Complexity (Cresskill: Hampton Press, Inc., 2008), xxiv.

19 Nietzsche spoke about the beautiful chaos of being (schöne Chaos des Daseins). Friedrich Nietzsche, Die fröhliche Wissenschaft (1882), in: Nietzsche (KGA), Abt. 5, Bd. 2 (1973), 201.

20 "Ontologically, the underlyingbeliefisthat of unorderand subjectivity; epistemologically, of heuristics or antipositivism; and teleologically, of a transformative nature." F. Nilson, Towards a Dialectic Complexity Framework: Philosophical Reflections. In: K.A. Richardson \& P. Cilliers (eds.), Explorations in complexity Thinking: Proceedings of the $3^{\text {rd }}$ International Workshop on Complexity and Philosophy (Mansfield: ISCE Publishing, 2007), 239.

21 The closest equivalent in Greek would be endoxa. 
ended and preliminary articulation. I briefly mention four movements of paradox within the preaching of Promise, namely: affirmation, provocation, migration, and anticipation.

\section{Preaching promise as affirmation}

The multi-coloured promises of God hinge on the Promise of God's Person and Presence, i.e. on the fact that God will not forsake or reject this world that we are part of. The Gospel of Christ speaks of incarnation, crucifixion, resurrection, inhabitation, and glorification - confirming God's enduring relationship with us, and indeed this planet called Earth. In her moving writings about prophetical preaching Dawn Ottoni-Wilhelm echo's this and reminds us that preaching is always an expression of "...the fact that God is compassionate, not deserting that which God has created; that God has made certain promises, expressing God's enduring faithfulness; and that there are alternative manifestations of God's in-breaking new world that can be discerned even in our darkest moments." 22

Preaching, understood in this sense, affirms, and indeed re-affirms God's Promise - even, and in particular, within the paradoxes of life. Daniël Louw describes this "theology of affirmation" as follows:

A theology of affirmation... seeks to deal with ontological issues that affect the status and identity of human beings ... Affirmation theology describes signification and ascribes human dignity and subject particularity. It emanates from the ontological "Yes" in Christ to our human being (as demonstrated through Baptism and celebrated in the Eucharist) and is demonstrated in new patterns of pneumatic living... ${ }^{23}$

This theology and consequently preaching of affirmation is not innocuous; on the contrary, it protests against any form of destructive ideology or so-called eternalized systems that refuse to believe that God has no, or

22 Dawn Ottoni-Wilhelm, "God's Word in the World: Prophetic Preaching and the Gospel of Jesus Christ", in Anabaptist Preaching: A Conversation between Pulpit, Pew \& Bible, ed. David B. Greiser and Michael A. King (Telford, PA: Cascading Publishing House, 2003), 84-91.

23 Daniël Louw, Cura Vitae. Illness and the Healing of Life (Cape Town: Lux Verbi, 2008), 30 . 
no longer has any, compassion with this world. Preaching Promise as affirmation within the paradoxes of life is to say that this universe is not cold and empty; not without the compassion of a faithful God. It is to unmask all powers and notions and movements and ideologies that destroy the dignity and identity of humans as humans. In this sense, preaching God's Promise as affirmation is not simply saying no!; It is rather saying yes! - because God is continuously saying Yes! to this world and its peoples.

In this paradoxical place called South Africa, we have been gifted with preachers that understood this theology of affirmation - people like Desmond Tutu, Allan Boesak, Beyers Naudé, and others. Desmond Tutu, for instance, never grew tired of "affirming" - swimming against the stream, and speaking out against structures that propagated the indignity of humans, and the divisions between them. ${ }^{24}$ He truly understood the art of para-doxa, of thinking, and preaching outside of, and against the popular opinion, but never leaving or rejecting those human beings whom he was addressing. He still does exactly that. The title of one of his most recent publications says it all: Made for Goodness. I quote:

God's gaze is like the gaze between lovers wrapped in a tender embrace. God looks at us the way a mother looks lovingly at her new-born baby. If you can see the loving gaze between mother and child in your mind's eye, you can begin a small meditation on being held in God's loving gaze. Once you are able to fix the gaze in your mind, put yourself in the sight line of the one gazing. Allow yourself to be the subject of that long, loving look. In this way you can imagine, then experience, the loving gaze that God turns to us. As we allow ourselves to accept God's acceptance, we can begin to accept our own goodness and beauty. With each glimpse of our own beauty we can begin to see the goodness and beauty in others. ${ }^{25}$

"As we allow ourselves to accept God's acceptance, we can begin to accept..."

24 The most important dimension of Tutu's communication in preaching as always the “'centrality of love/compassion' with its opposite 'judgmental to listeners"'. Vgl.HJC Pieterse; Fred Wester, "Communication Style" in Desmond Tutu's Message. A Qualitative Analysis. Ed HJC Pieterse (Kampen: Kok, 1995), 69. The aim of his preaching was "to weave them into a united group, putting their trust and hope in God the Liberator..." Pieterse; Wester, "Communication Style", 65-66.

25 Desmond Tutu and Mpho Tutu, Made for Goodness, And why it makes all the difference (Cape Town: Random House Group, 2010), 221. 
This, in my opinion, is preaching of the affirmative Promise of God, par excellence.

\section{Preaching promise as provocation}

We can already sense it: when we preach the affirmation of the Promise of God as para-doxa, we also provoke. We challenge even our so-called optimistic views on life. In the now almost iconic book of Douglas Hall, Lighten our Darkness, already published in 1976, he analysed the worldview of North Americans and came to the conclusion that they basically represent an officially optimistic society with a concomitant officially optimistic religion. ${ }^{26} \mathrm{He}$ understood these expressions of optimism as one of the major stumbling blocks for the proclamation of the Gospel of Hope. He contested that it is difficult to hope, truly hope, when you are optimistic. According to Hall, what most people heard from the preaching in the churches at that time was "... a positiveness that is phony and ridiculous: a bright and happy message that has all the depth of a singing commercial." 27 It is remarkable to note that he wrote those words even before the emergence of the so-called market-based megachurches or the popularity of the prosperity gospel industry.

In an interesting article, entitled Cross and Context: How my mind has changed, written many years later, he in fact - even though he has changed his mind on many accounts - reiterated his belief that optimism sabotages hope: "When we turn the story of Jesus into a success story, we both cheat ourselves out of its depth and effectively banish from our purview all those (and they are billions now) whose actuality precludes their giving themselves eagerly to stories with happy endings." ${ }^{28}$ There is indeed something like the banality of optimism - a banality that robs hope of its profundity. ${ }^{29}$

26 Douglas John Hall, Lighten our Darkness. Towards an Indigenous Theology of the Cross (Philadelphia: Westminster Press, 1976), 112.

27 Hall, Lighten our Darkness, 141.

28 Douglas John Hall, "Cross and Context: How My Mind Has Changed," The Christian Century 127, no. 18 (September 7, 2010), http://www.christiancentury.org/article/2010-08/crossand-context.

29 Terry Eagleton, Hope without Optimism (Virginia: University of Virginia Press, 2015), $1 \mathrm{ff}$. 
I am not sure whether Douglas Hall's original description of the North American people was in fact correct or whether he would still describe them as an officially optimistic society - in fact, I doubt it - but I know, sadly enough, that I could describe the current world view of at least a large number of South Africans as officially pessimistic. Broken promises have led to disillusionment, and a syndrome of distrust - a phenomenon to be seen on many levels of South African society. Whilst some churches and religious communities are still trusted by a number of South Africans, institutions like the police and in particular the parliament have to a large extent, lost the trust of the people. Politics, and politicians, are often seen as synonymous with promises being made, just to be broken. When you hear the word "politics", the word "promises" is conjured up, but also "distrust". In a recent survey, the following saddening data was made public:

$36,9 \%$ of South Africans feel it is unsafe to go to parks or open spaces; $25,4 \%$ feel it is unsafe to let children play in public spaces; $18,4 \%$ feel it is unsafe to let children walk to school; $17 \%$ feel it is unsafe to walk to work or downtown; $13 \%$ feel it is unsafe to walk to the café. ${ }^{30}$

According to many commentators, the South African "rainbow nation" is losing its kaleidoscopic charm. ${ }^{31}$ Many are lamenting the demise of many aspects of the era that was so boldly inaugurated by Nelson Mandela and others. Some of these laments express a longing for the "good old days" of apartheid, but others are lamenting what has gone wrong, without giving up the hope of an alternative future. If I may quote Desmond Tutu again: in a speech, delivered in 2006, and entitled What has happened to You, South Africa? he states his sadness concerning certain events in our country. ${ }^{32}$

30 Victims of Crime Survey. Graphic no 24, http://www.statssa.gov.za/publications/P0341/P03412013.pdf

31 See my discussion in Johan Cilliers, Between separation and celebration: Perspectives on the ethical-political preaching of Desmond Tutu. Stellenbosch Theological Journal 2015, Vol 1, No 1, 41-56.

32 In this speech, Tutu openly spoke about his dismay that someone like Jacob Zuma could be elected as President of South Africa. Although retired, Tutu still exposes injustices in society, whatever form it takes on. He once stated: "I do not do it because I like to do it... I cannot help it when I see injustice. I cannot keep quiet...” Desmond Mpilo Tutu, Hope and Suffering. Sermons and Speeches (Johannesburg: Skotaville Publishers, 1983), xiii. In recent times he has spoken out against the massacre of mine workers by police at Marikana, the waste of almost 250 million Rand in so-called "security upgrades" being done at president Jacob Zuma's private residence at Nkandla, and in particular 
My naiveté was that I believed that these noble attitudes and exalted ideals (of the liberation struggle, JC) would, come liberation, be automatically transferred to hold sway in the new dispensation. We South Africans were a special breed, and I believed we would show the world, hag-ridden especially in Africa by the scourge of corruption, that we were a cut above the hoi polloi. Wow! What a comprehensive let-down - no sooner had we begun to walk the corridors of power than we seemed to make up for lost time... The trouble with these people in government is that they've got power now and they believe that they're going to have power forever, and you have to keep warning them. The Afrikaner Nationalists thought they were invincible. Let me tell this ANC government what I told the Afrikaner Nationalist government: You may have power now, but you're not God. Remember: you're not God, and one day, you'll get your comeuppance. ${ }^{33}$

It may seem easier to hope, i.e. to believe in promises when you are pessimistic, but it is not necessarily so. Pessimism, like optimism, can sabotage hope. Pessimism can foster (the preaching of) false hope. One example of this would be the many forms of "prosperity gospel" being proclaimed throughout our country. Promises are made on the basis of religious convictions and mostly against the background of economical poverty and pessimism - promises of what seems to be unconditional health, wealth, and prosperity, but in fact being conditional on the quality of your "faith" and even the extent of your tithing. In many cases, those that make these promises grow rich, and those that these promises are made to, become even poorer. ${ }^{34}$

the plight of abused woman and children, and the fragmentation of family life in South African society. In a recent appearance on national television, he even said: "Be aware. We will start praying for the downfall of the ANC..." The paradoxes of the past, and the paradoxes of the present, still plaguing our country, perplex Tutu. He protested against the "God-with-us" theology of the Apartheid era, and he protests against the "God-with-us" theology of the current ANC Government, from whom we often hear statements like: "God was there at the inception of the ANC - therefore it is the only Party to vote for"; "If you vote for any other Party than the ANC, you will go to hell (sic)"; "If you vote for the ANC, it is your ticket to heaven"; "The ANC will rule until Jesus comes again..."; and so on.

33 Desmond Tutu, God is not a Christian. Speaking Truth in times of Crisis (London: Rider, 2011), 202, 212.

34 See the illuminating article by Gbote, E.Z.M. \& Kgatla, S.T., 2014, 'Prosperity gospel: A missiological assessment', HTS Teologiese Studies/ Theological Studies 70(1), Art. \#2105, 10 pages. http:// dx.doi.org/10.4102/hts. v70i1.2105 
The Promise of God, however, is para-doxa, contra popular opinions, be they optimistic or pessimistic; contra our understandings and expressions of glory and prosperity. Neither optimism, nor pessimism offers the keys to hope. Both optimism and pessimism keep us behind the bars of self-constructed promises and the disillusionment with these. The para-doxa of God's Promise in fact interrupts and even disrupts our constructs of hope and hopelessness; it is provocative in the deepest sense of the word. It calls forth that which could be hidden and masked, and challenges that which may be seen as popular opinion; it is the pro-vocare of para-doxa; the provocative paradox of God's Promise.

Preaching that expresses this pro-vocare, this provocation might and should sometimes be born out of a theology of anger. This theology of anger cries out: in God's Name, things cannot continue as they are... ${ }^{35}$

As I have stated before: we have been blessed in this country with preachers that practiced, and still practice, this theology of indignation, of interruption and holy provocation. More often than not they spoke out when large parts of the church were silent. They issued a challenge in the face of the incongruities of injustice. For instance, in a sermon on Acts 2:1-4 preached on Pentecost during the seventies, Allan Boesak, another one of our "Prophets from the South" in the struggle against apartheid, lampoons the church that has lost its critical edge in society, boldly stating: "And so the prophetic witness of the church, the voice of the Bride, is being exchanged for an unintelligible mumbling that is heard nowhere, and in the preaching the roar of the lion for the sake of righteousness (Amos) becomes nothing more than the squeaking of a scared mouse." 36

Indeed, (preaching of) the Promise of God is not necessarily a comforting dressing for an epidermal wound; not merely a soothing lullaby that intends slumbering and sleep...

35 This Theology of Anger is however not about anger merely for the sake of anger; on the contrary, it flows from the basis of compassion and hope. Indeed, “... it is clear that some of the most effective 'prophetic preaching' in our time by such dazzling voices as Desmond Tutu... has the power of indignation, but comes across as utterances of hope-filled, compassionate truth-telling largely free of rage.” Brueggemann, Ancient Utterance and Contemporary Hearing, Just Preaching. Prophetic Voices for Economic Justice. Ed André Resner, Jr. (St. Louis, Missouri: Chalice Press, 2003), 73.

36 Allan Boesak, Die Vinger van God. Preke oor Geloof en die Politiek (Johannesburg: Ravan Press, 1979), 37. Translated from the Afrikaans by Johan Cilliers. 
On the contrary, preachers that dare to articulate the Promise of God, become prophets that provoke. In recent years, it has often been asked: where have all these prophets gone? ${ }^{37}$

\section{Preaching promise as migration}

Preaching God's Promise however does not only entail affirmation and interruption and provocation. Its intention is to change the state of affairs, to move us forward towards transformation, a transformation that does not serve any political agenda, and yet serves them all, with contents of true justice, unity, and reconciliation. Preaching God's Promise “...embodies a kind of missional perspective namely promissio; i.e. to be send out, and to direct in a proactive way, life in terms of the fulfilled promises of the gospel." 38

The notion of missionality has become a type of theological buzzword in South Africa, at least in the Dutch Reformed Tradition to which I belong. This trend has been hailed and criticised. ${ }^{39} \mathrm{I}$ am of the opinion - which I debated in more detail elsewhere - that this trend of missionality offers many valuable perspectives, but in fact fails to challenge, to interrupt and provoke the systemic roots of, for instance poverty and inequality in this country. ${ }^{40}$ For me, we are simply missing the point with our missio.

37 Cf. my discussion in Johan Cilliers, Where have all the Prophets gone? Perspectives on Political Preaching. Stellenbosch Theological Journal 2015, Vol 1, No 2, 1-11.

38 Louw, Wholeness in Hope Care, 511.

39 Cf. Willem Saayman, Missionary or missional? A study in terminology. Missionalia 38:1 (April 2010), 5-16. Saayman pertinently asks whether the exchange of these two terms (missional for missionary) is not simply an effort to rebrand the latter, which has fallen into (anti-colonial) dispute? But, he states: "The definitive question is: is that what we really want to do? Is that what we really need to do to overcome our problem?...If we choose for missional, we choose at the moment unavoidably for emerging churches in postmodern contexts. How useful is such a choice for the theological discourse in the Third World in general and Africa in particular? Saayman, Missionary or missional? $15-16$.

40 Cf. my discussion in Johan Cilliers, "Poverty and Privilege": Re-hearing sermons of Beyers Naudé on Religion and Justice". Paper delivered at the International Summer School held at the University of the Western Cape, South Africa during 24-26 February 2015 on the theme: Religion, Law, and Justice. In collaboration with the Humboldt University, Berlin, The University of Stellenbosch, and the University of KwazuluNatal. To be published by International Journal of Public Theology. 
We might not be the first people to do so. The Netherlands has also seen its drive towards a missional church, with concomitant critical voices. Marcel Barnard, for instance, after giving an extensive overview of the countless activities that have been initiated to fuel this drive, of money being invested and personnel being appointed, expresses his misgivings, as follows:

After eight years we have discovered that nothing has come of these ideals. The Protestant Church in the Netherlands consists of spectacularly waning communities... Particularly in the years that the church claimed a new missional identity, she did not even come close to retain her dwindling numbers. The missional project has failed, or we should give a different meaning to the word "missional"... Against the backdrop of the waning church, missional language and pretences have become laughable. We are playing in a tragicomedy... Let us agree: from now on we will no longer be "missional". We call a halt to the missional activism. We rather return to the inner chamber. The inky night. The void. The great silence. The judgment of God. There, not visible to any outsider, we bend over the Scriptures and search whether we may not again, perhaps softly, hear the foolish voice of the Gospel... Here we gather around a table and share a tiny piece of bread and take a tiny sip of wine. And then we say (and we believe it ourselves): This is a sign of the great feast of all nations, with the best food and the best wines. And we inconspicuously walk an extra mile with those who need it - the refugee, the vulnerable elderly, and the abused child. Maybe a few people might ask themselves: what is it with those Christians? Then we will have little to say. Perhaps stutter: "You know, we belong to an executed Criminal, crudely hung up on a piece of wood." That is it. Let us simply be. Our God works in secret. That is his mission. ${ }^{41}$

On the one hand, it must be underlined: God is a God that moves. God is movement, not a monument. ${ }^{42}$ Dare I say: God is the ultimate cosmic

41 Marcel Barnard, De missionaire tragikomedie, in Woord en dienst 62/9 (2013), 34. Translated and paraphrased from Dutch by Johan Cilliers.

42 Cf. Johan Cilliers, "God in Granite? Aesthetic-Theological Perspectives on the Monumentalisation of Religion”, Scriptura 114(1), 2015, 1-13. 
Migrant? ${ }^{23}$ On the other hand, God's migration often goes undetected; God's pro-missio is mostly hidden away, incognito, indeed sub contrario.

And, to stay for a moment within the realm of the provocative: if God is the Migrating God, can God's body not be found amidst the many migrating bodies on this planet - in Africa, in Europe, on sinking ships in the Mediterranean Sea... ? Perhaps God's Body is being battered in Johannesburg, in frenzies of xenophobia? Or washed up on a beach in Turkey, fleeing from Syria? ${ }^{44}$ Perhaps we indeed have to go back into the inky night, the void, the great silence, the judgment of God - if we profess to preach about the enduring presence, the faithfulness of this God towards creation? Perhaps the provocation and the pro-missio of God's Promise must first shatter and redirect my own comfortable societal and theological constructs? It is, after all, by living and dying that one becomes a theologian, as Martin Luther said. ${ }^{45}$ Sadly enough, we more often than

43 See my discussion in Johan Cilliers, A Space for Grace. Towards an Aesthetics of Preaching (Stellenbosch: Sun Press, 2016), 137-138.

44 These words are written against the background of several catastrophic, global forms of forced migration that have taken place during 2015. Europe experienced its worst migration of people since the Second World War, with thousands flocking from wartorn countries such as Syria, to the shores of especially Greece, Italy and Hungary. The world was shocked when pictures of a drowned three-year-old Syrian boy, Aylan Kurdi, was recovered on the beach in Bodrum, Turkey - a fate shared with his mother and brother when their ship capsized en route to the Greek island Kos. In Western Africa, millions of people were uprooted by the violent actions of Boko Haram, with about 1.4 million Nigerians being forced to flee their country. South Africa has been plagued by unprecedented and widespread incidents of xenophobia already since 2008 . An estimated 62 people were murdered (12 of them South African citizens) and 25,000 people (some with refugee status, legal immigrants, illegal aliens, and even people with South African citizenship) were forced to flee their homes and livelihoods. Many reasons for this extreme form of social ostracization have been offered. Whatever the case, it is an extraordinary and ironic turn of events, taking place in a country renowned for its dismantling of apartheid, a period during which many freedom fighters found refuge in exactly the same countries whose people were being forced to leave South Africa in bus loads (Zimbabwe, Mozambique, Somalia, etc.), their homes being burnt down and their shops looted and pillaged. The precise number of people being killed or displaced in the recent xenophobic events of 2015 has not yet been released.

45 "I did not learn my theology all at once, but I had to search deeper for it, where my temptations took me. ... Not understanding, reading, or speculation, but living - nay, dying and being damned - make a theologian." Martin Luther, Tischreden (Luther's Table Talk, 6 vols. In the Weimar Edition), 1:146; D. Martin Luthers Werke, Kristische Gesamtausgabe (58 vols. Weimar: Böhlau, 1833 -), 5:163. 
not resist this living-and-dying-as-theologian. Indeed, we are our biggest paradox. $I$ am.

Perhaps our preaching should be taken out of its admirably formulated and avidly defended constructs, to be reborn out of the kairos of the marginalised, out of the crises of those on the edges, out of the cries of those on the borders of life and society. ${ }^{46}$ Perhaps this is where we will encounter the presence of the Faithful God; where we will see signs of God's Promises fulfilled, and being fulfilled: in the inky night; the void; the great silence; the judgment of God - where the executed Criminal, crudely hung up on a piece of wood, lingers? Perhaps we need to re-visit not only the paradoxes of life, but re-encounter the Paradox whom we call God within these paradoxes?

\section{Preaching promise as anticipation}

The movement of God often takes place incognito; the Cosmic Migrator often is hidden, sub contrario. And yet the happenstances of this movement and migration do not happen haphazardly. There is a direction, a telos, grounded in the faithfulness of God. In a certain sense, we can anticipate this Movement and Migration. We can learn the art and hermeneutics of expectation. We can be taught the wisdom of seeing-what-and-where it matters.

Preaching the Promise of God as anticipation is indeed about seeing, about vision, about pro-vision. ${ }^{47}$ Normally the term provision refers to the act or process of supplying or providing something, for instance when a supply of food and other things are needed. It however also implies something that is done in advance to prepare for something else that is still to happen. It is to see what is coming, and to act in the light of that; it is pro-vision that secures provision. It is seeing the images of the present-yet-hidden God, and

46 Cf. Ronald J Allan, Preaching as Spark for Discovery in Theology. Homiletical Theology. Preaching as Doing Theology. The promise of Homiletical Theology Volume 1. Ed David Schnasa Jacobsen (Eugene, Oregon: Cascade Books, 2015), 129-152.

47 Cf. my discussion in Johan Cilliers, Die optiek van homiletiek: Prediking as om-raming van perspektief. NGTT: Ned Geref Teologiese Tydskrif 2012; 53 (3\&4): 52-69. 
to imagine it; it is fides quaerens imaginem (faith in search of images, and imagination). ${ }^{48}$

Preaching God's Promise entails pro-vision, born out of anticipation, not only in the light of that which is still to happen (i.e. the fulfilment of God's promises), but to discern that which has already happened (i.e. God's fulfilled promises). It is indeed about discernment, about seeing deeper than the surface, about interpreting that which might seem like a contradiction and paradox, to be in fact a sign of God's Promise of enduring Presence.

I am reminded of the writings of the somewhat enigmatic author Nassim Nicholas Taleb, who argued that change, even change that might seem interruptive or disruptive at the time, could in fact be embraced as the beginnings of new life. A candle might be put out by wind, he says, but wind can also create a new fire - which he interprets as a symbol of new life..$^{49}$ He poses the question: how do we react to risks, to surprises, unexpected events, dramatic changes, even shocks that have far-reaching effects that rearrange the order as we know it? Sometimes, he says, some of these events might be completely strange, like the appearance of a black swan - and it is impossible to be prepared for such a strange happening. The question is, however, how we react to this black swan, i.e. how we see it. For him, the challenge is to accept these strange twists and turns of history, to ride the wind, so to speak, so that you may be strengthened by this. We are fragile, Taleb would admit, but we must also learn the art of being antifragile - a term that he coins himself - of seeing, and interpreting, and reacting to the inexplicable phenomena of life..$^{50}$

Obviously, these sentiments of Taleb could be criticised and misunderstood. Taleb is, for instance, not advocating a lifestyle of martyrdom-seeking; nor does he fall prey to a new "banality of optimism". But he calls for a form of vision that sees deeper, forward, if I may say: that calls for anticipatory

48 See my discussion in Johan Cilliers, Fides quaerens imaginem: The quest for liturgical reframing. Scriptura: International Journal for Bible, Religion and Theology in Southern Africa 2012; 109: 16-27.

49 Nassim Nicholas Taleb, Antifragile: Things That Gain from Disorder (New York: Random House, 2012), 1ff.

50 Nassim Nicholas Taleb, Antifragile, 44ff. See also Nassim Nicholas Taleb, The Black Swan: The Impact of the Highly Improbable (New York: Random House, 2007). 
pro-vision. Preaching, in my opinion, takes place within this tension of fragility and antifragility; it is to fully accept the brokenness of life, but simultaneously to point imaginatively towards an alternative: a future that has already dawned amongst us, as the adventus of God's continuous coming-towards-us. ${ }^{51}$

This movement between being fragile and antifragile, could in more traditional terms be called hope. Hope is to anticipate, and imagine, provisionally, the future. In the words of Daniël Louw: "The root of the Hebrew word for hope has the connotation of a bowstring, or an interrelated quivering web of meaningful connections; hope is like the trembling of a cord; it moves and pushes one forward towards the future. Hope is to stretch oneself out towards what is becoming and to anticipate the content of expectation in advance." 52

The Promise of God, that creates hope, is something completely different than the promises that operate in optimism, or are broken in pessimism. The promise of God is of a different order; it points towards a lifestyle, i.e. a faith that says: Even if... there is nothing, yet I will glorify God, like the prophet Habakkuk did. ${ }^{53}$ It represents a stance that says: I will live within, and with, the paradoxes of life, as if... God is faithfully present, even if I experience the contrary, because God is present. In my opinion, preaching of the Promise of God perpetually moves within this tension of even if... as if.

Preaching of the Promise of God fosters sensitivity for the unexpected; it creates anticipation of the revelation of the White Dove of God's blessing. One of our own poets, Sheila Cussons, articulated this event of the graceful in-breaking of the unexpected in a beautiful poem, entitled Die Sagte

51 Cf. Johan Cilliers, Time out. Perspectives on liturgical temporality. NGTT. 2009: 50 (land 2): 26-35.

52 Louw, Wholeness in Hope Care, 502. Or, in the words of James Childs: "It is a promise from God, sealed in cross and resurrection, a basis for hope. The power of this gracious promise energizes our efforts to anticipate this divine future by addressing our own complicity and seeking the changes that serve all people." James M Childs, Enabling Grace. Just Preaching. Prophetic Voices for Economic Justice. Ed André Resner, Jr. (St. Louis, Missouri: Chalice Press, 2003), 43.

53 Habakkuk 3:17-19. 
Sprong (The Soft Leap). ${ }^{54}$ It is of course impossible to do justice to the poem with any translation, but in essence Cussons believes that grace although she never uses that word - comes when you least expect it; it is an illumination of the mind, as light as a feather, fleeting, but precise - and if you experience this touch of grace as being feather-light, and yet it lingers for so long, how powerful would it not be if grace exerts a firmer grip on you? Grace comes when you do not expect it; it is something that strikes your consciousness in its deepest life; it is something like a soft leap, that fills you with joy, amazement, recognition - and if this is so moving and life-changing, how much more if grace no longer leaps softly, but becomes a graceful insurgence, she wonders?

Life is filled with paradoxes. But in-between these paradoxes, and within these paradoxes, we experience the soft leaps, the light touches, sometimes the firmer grips, of grace, i.e. of the Promise of the enduring faithfulness of the Present God. Perhaps this Presence is the most fundamental of all Paradoxes - the Paradox that grants us life within all other paradoxes.

To live with this Paradox of all Paradoxes within, and from time to time, against life's paradoxes, signifies a particular form of hope. It provokes us to see, and to move - perhaps even dance, from time to time. In fact, there seems to be a definitive relationship between hope and dance. Joan Erikson wrote the following poem only weeks before her husband's death: ${ }^{55}$

\section{Hope}

The word "Hope" the learned say

is derived from the shorter one "Hop"

and leads one into "Leap".

Plato, in his turn, says that the leaping

of young creatures is the essence of play-

So be it!

To hope then, means to take a playful leap into the future - to dare to spring from firm ground -

54 Sheila Cussons, Die Sagte Sprong (Kaapstad: Tafelberg Uitgewers, 1979), 7.

55 Quoted in Donald Capps, Agents of hope. A pastoral psychology (Minneapolis: Fortress Press, 1995), 176. 
to play trustingly - invest energy, laughter;

And one good leap encourages another-

On then with the dance.

To dance is to hop in hope. It is to leap - like a young creature - into the future. It is to leap forward because of the soft leap of grace that has filled your being. In the well-known words of Rubem Alves: To hope is to hear the melody of the future. Faith is to dance it. ${ }^{56}$

Preaching God's Promise is to invite one to dance, sometimes only as an affirmative shuffle; sometimes as a provocative tango; perhaps as a joyful hip-hop of hope - but always to move; because you see the future in the present. It lives in anticipation; it has pro-vision, and therefore provides a different set of keys that unlocks the cell, and brings an end to bars, or at least reveals its ultimate powerlessness.

Writing these words, I was reminded of an iconic artwork by nobody else than former President Nelson Mandela, entitled Bars and Key, or also Freedom. ${ }^{57}$ This artwork simply consists of four black lines that Mr. Mandela drew slowly and deliberately with his fingers to represent the bars of his cell, together with an exact bronze replica of his cell key. It seems so simplistic, so stripped of grandeur, and yet it depicts so much. Here we indeed have $a$ masterful expression of paradox: bars that indicate confinement and a key that can unlock - and it is exactly in their juxtaposition that the promise of freedom lies.

This artwork affirms the dignity of human life: it cannot be kept behind bars. Mr. Mandela movingly describes the systemic onslaught of the jail he was in; not only the reduced space of his cell ( 6 feet by 2 feet), but in particular the reduction of humanity to a number $-466 / 64 .{ }^{58} \mathrm{But}$, as we know, the system could not suppress the dignity of Nelson Mandela.

As such, the artwork provokes: It not only depicts the systems that seek to incarcerate human dignity, it fundamentally interrupts and provokes these systems. We do not only see the bars, but the keys also - signifying

56 Rubem A. Alves, Tomorrow's Child: Imagination, Creativity, and the Rebirth of Culture (London: SCM Press Ltd, 1972), 195.

57 Source: http://nelsonmandelaart.co.za/product/bar-and-key/

58 Nelson Mandela, Long walk to freedom (Randburg: Macdonald Purnell, 2000), 369-370. 
the ultimate end of these and all bars. This artwork moved me, because it represents the aesthetical depiction by a human being who believed that those on the margins, those who had been forcefully removed, those who had no other option than migration, has hope, always hope.

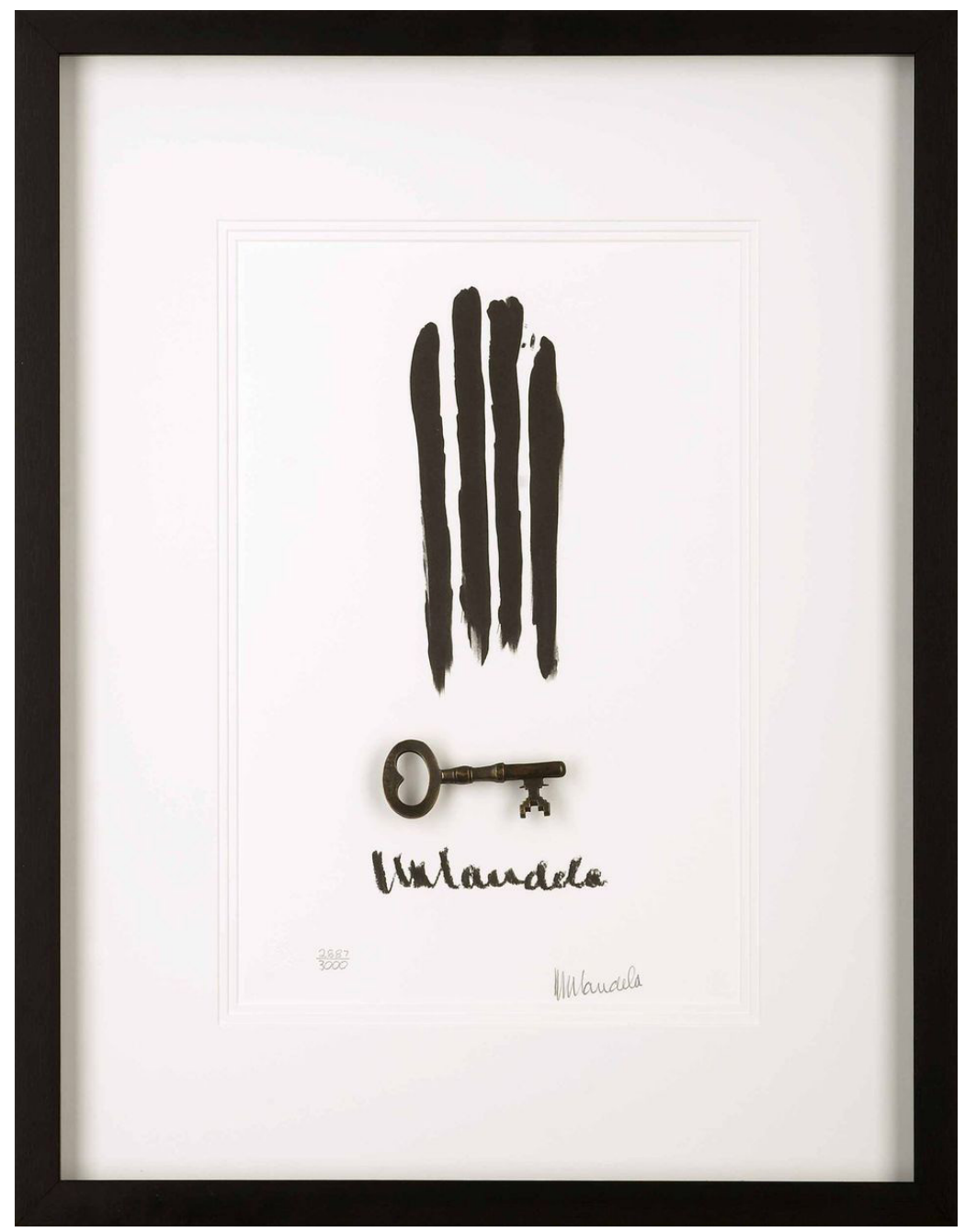


Four lines and a key - but it opens up vistas of new beginnings. It sees forward. It anticipates, even if the anticipation took 27 years towards its fulfilment. "I always knew that someday I would once again feel the grass under my feet and walk in the sunshine as a free man." 59

Surely a moving "sermon" in itself?

Surely a masterful expression of paradox, but also profound depiction of promise?

Perhaps a soft touch of grace - or perhaps even a firmer grip - for "such an unlikely lot", like us?

59 Mandela, Long walk to freedom, 376-377. 